\title{
Transformation of Dry-Steppe Soils under Long-Term Agrogenic Impacts in the Area of Ancient Olbia
}

\author{
F. N. Lisetskii and M. E. Rodionova \\ Belgorod National Research University, ul. Pobedy 85, Belgorod, 308015 Russia \\ e-mail: liset@bsu.edu.ru \\ Received September 10, 2013
}

\begin{abstract}
The results of the study of dark chestnut soils (Kastanozems) differing in the time and intensity of their agricultural use and in the duration of the fallow stage are analyzed. Soil sequences differing in the character of their agrogenic changes were studied in the rural area of ancient Olbia with a centuries-long history of diverse economic activities, including crop growing. The agrophysical, agrochemical, and geochemical characteristics were examined in order to assess the soil transformation processes in a sequence from the initial virgin soil to the cultivated soil of the antique period in the fallow stage, the soil under recent (three-five years) fallow, and modern plowed soils in the area of ancient farming. It was found that the contents of humus, total nitrogen, and carbonates; the water stability of the soil aggregates; and the portion of coprolites in the agronomically valuable aggregate fraction are sensitive indicators of the duration of the agrogenesis in the dark chestnut soils. The manifestation of agrogenic processes at different hierarchical levels of the spatial and temporal organization of the soil system depended on the duration and intensity of the farming practices. Temporal abandonment of intensely cultivated lands in traditional farming practices with periodic initiation of the natural processes of restoration of the soil fertility can be considered a suitable measure to regulate agrogenic loads on the soils with the aim to enhance the self-organization processes in the soil system.
\end{abstract}

Keywords: ancient farming, pedogenesis, old-arable soils, indicators of agrogenesis, soil memory, dark chestnut soils (Kastanozems)

DOI: $10.1134 / \mathrm{S} 1064229315040055$

\section{INTRODUCTION}

Soils that have been subjected to long-term continuous cultivation (or discontinuous cultivation with fallow stages) bear valuable information important for our knowledge of the mechanisms of soil evolution. In response to the agrogenic loads, the soil system, as well as the entire agrolandscape, reveals its natural potential for sustainability in terms of its stable structural features and dynamic processes. Diverse chain reactions of transformation and adaptation or degradation take place in such soils [24]. In this context, it is of great interest to study polygenetic soils shaped in agrolandscapes with long-term history of their agricultural use. In the recent decades, new possibilities have appeared in the study of evolutionary changes in the substantive and energy changes of soil systems under the impact of the former land use practices. Remote sensing data make it possible to detect and reconstruct the spatiotemporal organization of old-arable landscapes [7, 29, 38, 39]. Geoarchaeological and pedoarchaeological methods are actively applied to the study of historical cultural landscapes [34, 35, 37, 42, 43, 45]. An historical approach to the study of soil evolution [10] implies the analysis of the relationships between the evolutionary changes in the soil properties and the (1) applied farming systems and the (2) duration of the agricultural use of the soils. However, the analysis of publications [46] shows that the results of the impact of ancient farming on soils are difficult to interpret on the basis of records in the soil system. In this context, further development of approaches aimed at revealing and interpreting information stored in soils as natural archives is necessary.

The aim of our work was to find the most informative indicators of agrogenic processes on the basis of the analysis of evolutionary changes in the properties of dry-steppe soils in a rural area of ancient polis.

\section{OBJECTS AND METHODS}

The studied area is located on the right bank of the Bug Estuary between the villages of Parutino and Dneprovskoe (Ochakov district of Nikolaev oblast of Ukraine) (figure). This territory belonged to the rural area of Olbia, an ancient Greek polis (6th century $\mathrm{BC}-4$ th century AD) on the northern coast of the Black Sea. The analysis of satellite images of this area showed the presence of geometric patterns related to the boundaries of ancient agricultural fields. Land surveying of this territory was performed in the first half of the 5 th century BC, when the boundaries of the particular land plots were fixed in space. It is probable that 


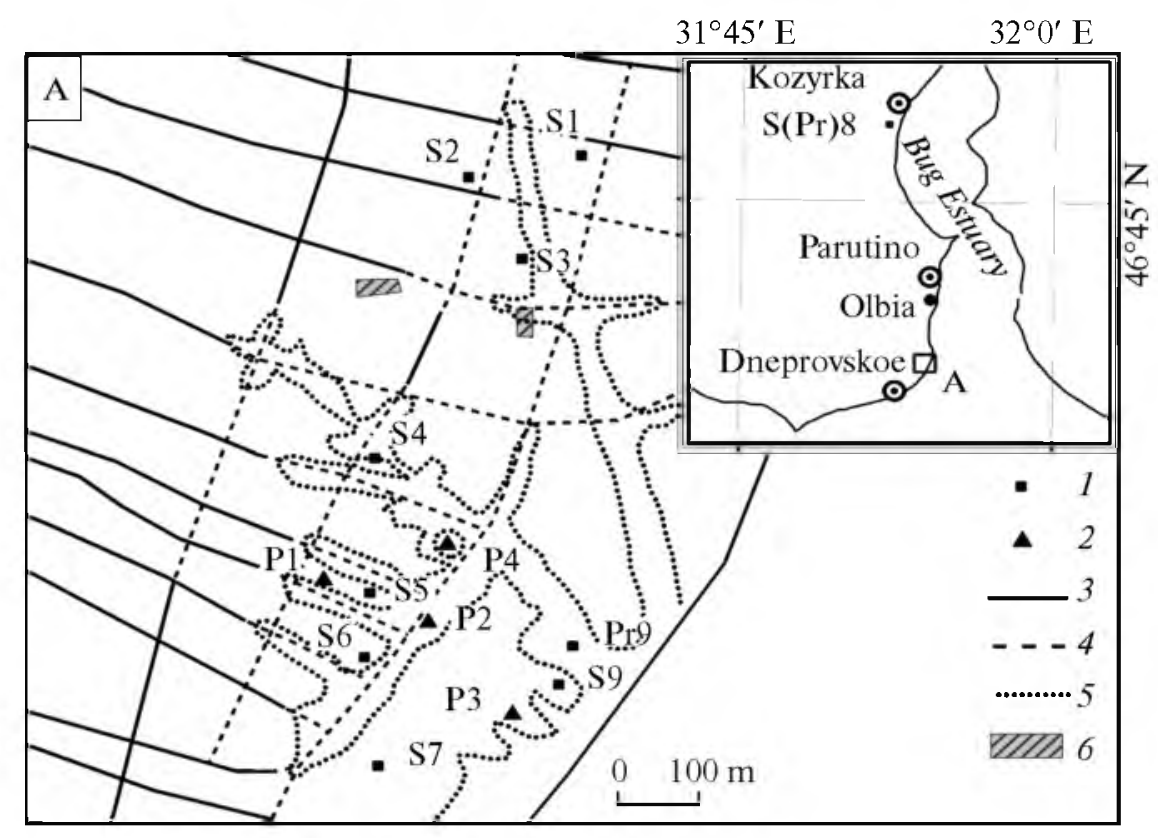

Schematic map of field studies in the Lower Bug reaches (within the rural area of ancient Olbia) and (A) the Krestovyi Ravine key site: (1) sampling points of soils (S) and parent materials (Pr), (2) location of key soil profiles (P), (3) boundaries of ancient land allotments (as seen on satellite images), (4) supposed boundaries of land plots, (5) modern boundaries of erosional landforms, and ( 6 ) basements of buildings.

legal land ownership rights were established in the same time period. The key site of our studies was found $4.4 \mathrm{~km}$ to the south of Olbia within the largest land plot of the ancient time as identified by remote sensing methods [33, 38].

It belongs to the Prichernomorskaya Lowland with absolute heights of up to $50 \mathrm{~m}$ a.s.1. and is characterized by a dry and moderately hot climate; the coefficient of climatic moistening (the precipitation-topotential evaporation ratio) is 0.4 . Before its agricultural development, this area was under fescue-feather grass steppes forming on slightly solonetzic dark chestnut soils. At present, it belongs to a large agricultural enterprise specializing in cultivation of grapes and cereals; the portion of agricultural lands reaches $86 \%$ of the total area. The modern environmental conditions of the steppe zone in the lower reaches of the Bug River are characterized by the deficit of moisture, unstable precipitation with considerable variations during the growing season and from year to year, and frequent droughts and dry winds. According to generalized paleogeographic [9] and pedochronological [16] data, the bioclimatic conditions in this region during the period of ancient farming were relatively stable; the energy potential of the pedogenesis was $23 \%$ lower than that in the modern period.

The land use patterns of the antique period and later time were identified using aerial archive photos and modern satellite imagery from Google Earth and TerraLook resources.
The agrogenic changes in the soil properties were studied on a series of plots differing in the duration and intensity of the agricultural impacts with the other factors being relatively stable. The following objects were examined: virgin plots (S8, S9), a cropland of the antique period (at present, under long-term fallow) (S3-S6), recent (three-five years) fallow plots (S2, S7), and a modern cropland in the area of ancient farming (S1). Soil samples of standard volume $\left(10 \mathrm{dm}^{3}\right)$ were taken. Samples of the parent material (loess-like loam) were taken from the Chorizon (at the depth of $1.2 \mathrm{~m}$ ) in the reference profile of a virgin soil (Pr8) and in a soil profile beyond the farming area ( $\operatorname{Pr} 9$, the Krestovyi Ravine). The assessment of the agrogenic changes in the soils was based on the analysis of several groups of soil properties.

The group of agrophysical properties included data on the (a) aggregate-size distribution according to N.I. Savvinov (the analysis was performed in triplicate), (b) the water stability of the aggregates according to [2] (the analysis was performed in five replicates; 50 aggregates from each of the size fractions $(5-3,3-2$, $2-1$, and $1-0.5 \mathrm{~mm}$ ) were analyzed), (c) the amount of coprolites (in triplicate), and (d) the water stability of the coprolites. These data were used to calculate the coefficient of soil aggregation $\left(K_{\text {aggr }}\right)$, the mean weighted diameter of the water-stable aggregates $(d)$, and the biogeneity of the soil aggregates (the mean weighted portion of coprolites in the total amount of aggregates, \%). 
The group of agrochemical properties included data on the contents of humus (determined by the method of Tyurin) and labile soil organic matter (by the method of Egorov); the fractional composition of the humus (by the method of Ponomareva and Plotnikova); the contents of total nitrogen (by the method of Kjeldahl), available phosphorus $\left(\mathrm{P}_{2} \mathrm{O}_{5}\right)$, and potas$\operatorname{sium}\left(\mathrm{K}_{2} \mathrm{O}\right)$ (by the method of Chirikov); the soil reaction $(\mathrm{pH})$; and the content of carbonates $\left(\mathrm{CO}_{2}\right)$ determined by routine methods.

The group of geochemical characteristics of the soils included two coefficients calculated from the data on the bulk elemental composition of the soil mass (determined by the method of X-ray Fluorescence Spectroscopy): the coefficient of eluviation $\left(K_{\mathrm{e}}\right)$ and the Shaw coefficient $R$. The coefficient of eluviation was calculated according to the following equation: $K_{\mathrm{e}}=\mathrm{SiO}_{2} /$ $\left(\mathrm{MnO}+\mathrm{CaO}+\mathrm{K}_{2} \mathrm{O}+\mathrm{MgO}+\mathrm{Na}_{2} \mathrm{O}\right)$ [40]. The coefficient $R$ suggested by Shaw [44] was somewhat modified and calculated as the geometric mean of the products of the ratios of the contents of the trace elements ( $\mathrm{Mn}, \mathrm{Zn}, \mathrm{Cu}$, Ti. Ni, Cr, and V) in the soil to those in the parent material.

\section{RESULTS AND DISCUSSION}

Stages of agrarian history. In the 6th century BC, ancient Greeks colonized the coastal zone of the Bug Estuary. In the second half of this century, the rural area of Olbia with its specific land use and settlement systems and transport network was shaped [5]. Though there are certain chronological gaps in our knowledge of the further history of Olbia, it is known that settlements of ancient Greeks existed there up to the middle of the 3rd century AD, when the first settlement belonging to a different culture (the Chernyakhovsk settlement) appeared in this area [12]. On a smaller scale, land cultivation in the rural area of ancient Olbia continued in the 4th century AD. Thus, the ancient history of the agricultural land use in the lower reaches of the Bug River lasted for nearly a millennium.

In the Archaic period (the 6th-first half of the 5 th century $\mathrm{BC}$ ), when land reserves were considerable, the colonists applied a shifting cultivation system [12]: plowing of virgin land-cropland (6-8 years) abandoned land (long-term fallow). The duration of the fallow stage necessary to restore the soil fertility was empirically determined with due respect for the local conditions. Commodity crops-barley, wheat, and millet - were grown. Later, in the 5th-3rd centuries $\mathrm{BC}$, the fallow system of farming was applied: cropland ( $3-8$ years)-fallow ( $8-15$ years) - cropland (3-8 years). Then, with a general rise in the land deficit, the duration of the fallow stage was reduced from $6-12$ to $6-8$ and $3-5$ years [25]. Crop rotation systems were applied, which is proved by findings of the remains of synchronously grown two-three cereal crops in the settlements. The land use pattern with sep- arate fields within the same land allotment became more complicated.

In the 19th century, the portion of plowed land in this region varied from $10 \%$ (in the 1820 s) to $34 \%$ (in the 1880s); large land areas were used for sheep breeding [19]. The fallow system of agriculture existed up to the 1860 s and implied crop cultivation on the plots for 3-8 years with subsequent fallowing for $4-5$ to $10-15$ years. In 1867 , a well-known agronomist (Sovetov) wrote the following: "land owners in steppe regions know that reasonable yields can be gained 4-5 times from virgin land, 3-4 times from long-term (10-15 years) fallow land, and only once from short-term (<3 years) fallow land" [30, p. 76]. This situation changed in the 1880s [27]: most of the land plots were subjected to continuous cultivation or grazing loads; fallow stages were short. The removal of nutrients (in particular, $\mathrm{N}$ and $\mathrm{K}_{2} \mathrm{O}$ ) from the soils of cultivated fields and the enrichment of pastures with nutrients $(\mathrm{K}, \mathrm{Ca}, \mathrm{N}$, and $\mathrm{P}$ ) from manure were the major biogeochemical effects of this system.

When a cultivated field was abandoned (fallowed) for 25-30 years, it was covered again with feather grass (Stipa capillata). As noted by Pachoskii, "feather grass on pastures and hayfields never reaches such luxuriant development as on the reserved land of Askania Nova because of the excessive exploitation of these lands" $[26$, p. 27]. At the same time, feather grass proved to be tolerant to pastoral degradation.

A short-term period of a considerable decrease in the area of plowed fields was related to the social and political shocks: in 1910, plowland occupied $67 \%$ of the area in the Odessa district, and the area of virgin steppe lands and pastures was $10.4 \%$; fifteen years later (in 1925), only $6.3 \%$ of the territory was under plowland, and the area of pastures and long-term fallow lands increased by up to $20 \%$ (in the Ochakov area). At present, plowed fields occupy $63 \%$ of the entire territory.

Local features of the transformation of the land use. The pattern of settlements of ancient farmers attests to the long-term history of land cultivation in this area during the antique time. A group of settlements dating back to the 6th to 3 rd centuries $\mathrm{BC}$ was discovered by archaeologists in this area. A multilayered settlement (Dneprovskoe 2) that existed from the second half of the 5 th to the beginning of the 2 nd century BC is known $4.5 \mathrm{~km}$ to the southwest of the studied polygon. In the first centuries AD, a town was founded in the same place.

The Krestovyi Ravine key polygon of our studies is a unique area within the entire ancient Olbia state. In this area, the initial virgin soils are preserved in some places. It should be noted that the coastal zone was not subjected to cultivation in the antique time. However, because of the transgression of the sea and coastal abrasion, the shoreline has shifted up to $300-400 \mathrm{~m}$ in the inland direction. The orientation of ancient roads 


\section{LISETSKII, RODIONOVA}

parallel to the shoreline indicates that some interravine plots cultivated in the antique time were abandoned later and have not been cultivated since then (plots S4-S6). The reconstruction of the boundaries of the ancient land plots shows that the plots found between actively growing ravines (plots $\mathrm{S} 5$ and S6) had a shorter duration of cultivation in the antique period in comparison with other plots (plots S3 and S4) found in more stable geomorphic positions. Thus, within a relatively small area, soils with different durations of cultivation in the antique time can be found.

The unusual geometric pattern of the thalwegs of the erosional network is reflected in the name of the polygon (Krestovyi means crosslike): apical parts of erosional cuts are confined to the ancient boundaries between separate land plots [33]. These boundaries were fixed by artificial levees constructed about 2400 2500 years ago. After their construction, radical changes in the runoff pattern took place. Thus, the apical parts of the nine modern ravines have their continuation on the adjacent arable fields. On the aerial archive photos of this territory, this continuation is seen in the form of light-colored strips against the darker background color. It is probable that these strips correspond to the ancient boundaries between land plots. The average distance between them $\left(S_{x}\right)$ is $114 \pm 19 \mathrm{~m}$ $\left(x \pm t_{05}\right)$. Less distinct boundaries can be traced inside; the average distance between them is $37.5 \pm 3.8 \mathrm{~m}$. The modal length of the plots is about $280 \mathrm{~m}$. From these data, we can estimate the area of a single land allotment in the antique period at about 0.32 ha.

The anthropogenic factors that led to the activation of linear erosion within the Krestovyi Ravine polygon were already considered by one of the authors [15]. At the same time, a comparison between the potential washout of the soil ( $2 \mathrm{t} / \mathrm{ha}$ per year) using the model developed by Shvebs (with due account for the regional factors of erosion) [18] with the real results of erosional processes (the thickness of the pedolithosediments accumulated in the bottom of the accumulative part of the ravine reaches $2.33 \mathrm{~m}$ ) shows that the intensity of the erosion in the past 150 years (the period of active agricultural development of the territory) has been insufficient to explain such a considerable accumulation of eroded sediments. This leads us to a conclusion about the much longer history of cultivationinduced erosional processes in this area, which could have begun in the antique period.

The history of the agricultural development of the local soils can be generalized as follows: virgin soilarable land of the antique period (for at least 140 years) - (a) abandoned land (postantique fallow, 2250 years) or (b) postantique fallow (2100 years) extensively cultivated land (about 110 years) - intensively cultivated land (about 40 years). Fallow fields of different ages may exist within the area cultivated in the past 150 years. To study the soils of agrolandscapes with such a complicated history, it is reasonable to relate the soil areas to the areas for which the history of their natural and anthropogenic development has been reconstructed [39]. We have arranged the studied plots into the following series reflecting the increase in the agrogenic loads on the soils: $\mathrm{S} 2>$ $\mathrm{S} 1>\mathrm{S} 6>\mathrm{S} 7, \mathrm{~S} 3>\mathrm{S} 4>\mathrm{S} 5>\mathrm{S} 8, \mathrm{~S} 9$.

Soil morphology. Key soil profiles within the Krestovyi Ravine polygon were studied on the plot subjected to cultivation in the antique period (P1), on fallow plots near currently cultivated fields (P2 and P3), and on the virgin plot (P4). The latter soil profile was characterized by the following horizonation: $\mathrm{AO}$, $0-5 \mathrm{~cm}$; A, 5-28 cm; B1, 28-47 cm; B2, 47-70 cm. The upper boundary of effervescence with $\mathrm{HCl}$ was at the depth of $48 \mathrm{~cm}$. Another profile of a virgin soil was described near the village of Kozyrka (plot S8) in pit 54 [13]. This soil $(n=59)$ had a humus (A) horizon $32.7 \pm 0.6 \mathrm{~cm}\left(x \pm t_{05} S_{x}\right)$ in thickness; the thickness of the entire humus layer $(A+B 1)$ reached $48.5 \pm 0.6 \mathrm{~cm}$. The profiles of the virgin soils ( $\mathrm{P} 4$ and S8) correspond to dark chestnut soil with the eluvial-illuvial differentiation of carbonates. They are close in their morphology to the reference soil of dry steppes on the northern coast of the Black Sea studied in the Askania Nova Biosphere Reserve. However, the Ochakov district (where our polygon is found) has a less continental climate with a higher supply of heat (the sum of daily temperatures $>10^{\circ} \mathrm{C}$ is 120 degree days higher than that in the Askania Nova Biosphere Reserve) and moisture (the annual precipitation is about $50 \mathrm{~mm}$ higher). The local virgin soils can be classified as dark chestnut soils of warm facies with periodic soil freezing.

A comparison of the morphology of soil profiles P1-P3 with the morphology of profile P4 shows that the agrogenic load on the soils has led to some decrease in the thickness of the humus (A) horizon, higher variation of the total thickness of the humus layer (A + B1 horizons), and a deeper boundary of effervescence with $\mathrm{HCl}$.

It was found that the morphology and classification position of the chestnut soils were stable during the Late Holocene stage of their development (within the last 3500-3000 years) [32]. However, the classification position of soils in the dry-steppe zone subjected to the long-term impact of ancient farming has changed. At present, these soils are classified as slightly solonetzic deep dark chestnut soils with deep effervescence [13]. The analysis of a large set of pedochronological data [17] showed that the thickness of the humus horizons of the newly formed soils (with an age of up to 2600 years) is the same in the zones of southern chernozems and dark chestnut soils. Hence, it can be supposed that the climatic conditions of that period have been relatively close to one another in these zones.

In the full-profile mature steppe soils, the wellbalanced processes of humus accumulation and its redistribution in the profile are diagnosed by the approximately equal thicknesses of the humus-accumulative (A) and transitional (B1) horizons so that 
Table 1. Assessment of agrogenic changes in the structural state of the topsoil layer $(0-20 \mathrm{~cm})$ of dark chestnut soils in the area of antique land plots

\begin{tabular}{|c|c|c|c|c|c|c|c|c|}
\hline \multirow{2}{*}{ Land use } & \multirow{2}{*}{$\underset{\text { point }}{\text { Sampling }}$} & \multirow{2}{*}{$\gamma, \mathrm{g} / \mathrm{cm}^{3}$} & \multirow{2}{*}{$\begin{array}{l}\text { Munsell color } \\
\quad \text { (dry) }\end{array}$} & \multirow{2}{*}{$\begin{array}{c}\text { Portion } \\
\text { of coprolites } \\
\text { in the AVA, } \\
\%\end{array}$} & \multicolumn{3}{|c|}{$\begin{array}{l}\text { Aggregate-size distribution, } \\
\% \text { of the mass of air-dried soil }\end{array}$} & \multirow{2}{*}{$K_{\text {aggr }}$} \\
\hline & & & & & $>7 \mathrm{~mm}$ & $7-0.25 \mathrm{~mm}$ & $<0.25 \mathrm{~mm}$ & \\
\hline \multirow[t]{2}{*}{ Virgin land } & $\mathrm{S} 8$ & 1.14 & $10 \mathrm{YR} 5 / 2.5$ & 22.7 & 9.4 & 75.2 & 15.4 & 3.0 \\
\hline & S9 & 1.20 & $10 \mathrm{YR} 4 / 2$ & 40.1 & - & 73.6 & 26.4 & 2.8 \\
\hline \multirow[t]{3}{*}{ Postantique fallow } & S3 & 1.30 & $10 \mathrm{YR} 4 / 2.5$ & 33.2 & 14.9 & 63.7 & 21.4 & 1.8 \\
\hline & S4 & 1.22 & $10 \mathrm{YR} 5 / 2$ & 31.2 & 16.4 & 60.5 & 23.1 & 1.5 \\
\hline & S5 & 1.30 & $10 \mathrm{YR} 5 / 3$ & 43.8 & 14.5 & 73.2 & 12.3 & 2.7 \\
\hline \multirow[t]{2}{*}{ Fallow of $3-5$ years } & S2 & 1.28 & $10 \mathrm{YR} 5 / 3$ & 6.7 & 21.7 & 69.8 & 8.5 & 2.3 \\
\hline & S7 & 1.33 & $10 \mathrm{YR} 5 / 3$ & 11.9 & 18.7 & 52.2 & 29.1 & 1.1 \\
\hline $\begin{array}{l}\text { Cropland in the area } \\
\text { of ancient farming }\end{array}$ & $\mathrm{S} 1$ & 1.02 & $10 \mathrm{YR} 5 / 3.5$ & 8.4 & 20.7 & 71.7 & 7.6 & 2.5 \\
\hline
\end{tabular}

Hereinafter, the numbers of sampling points correspond to those in the figure; $\gamma$ denotes the soil bulk density.

the $\mathrm{B} 1 / \mathrm{A}$ ratio is equal to $1.0[14]$. In the medium and heavy loamy dark chestnut soils of the region $(n=144)$, the $\mathrm{B} 1 / \mathrm{A}$ ratio is $28 / 28=1$. In the old-arable soils (profile $\mathrm{P} 1$ ), this ratio is higher than 1.0 owing to the deep humus profile.

Physicochemical properties of the topsoil $(0-20 \mathrm{~cm})$ in the agrogenic soil sequence. In terms of the Munsell soil color name (Table 1), the darkest color (grayish to dark grayish brown) is typical of the virgin soils (S8 and S9) and the soil of a long-term fallow (S3). The soils of the fallow plots (S4, S6) are somewhat lighter (grayish brown). The other soils have a brown color of the topsoil horizon. In the field descriptions, the soil color names were somewhat different [28]; it was noted that the graybrown color of the A horizon is typical of the dark chestnut soils in contrast to the gray color of the southern chernozems.

The dark chestnut soils developing from the loesslike loam have solonetzic features in their physical properties: the structure of the topsoil horizons is relatively loose, and the illuvial horizon is very compact; the water stability of the soil aggregates is relatively low.

The agronomically valuable aggregate (AVA) fraction is represented by crumbs and granules $1-7 \mathrm{~mm}$ in diameter; smaller aggregates $(0.25-1.0 \mathrm{~mm})$ can be considered as a reserve for further aggregation.

According to our data, the dark chestnut soil of the Askania Nova Biospheric Reserve contains up to $80 \%$ aggregates $0.25-7 \mathrm{~mm}$ in diameter in its humus horizon (A, 9-28 cm). The portion of coprolites in the agronomically valuable aggregate fraction $(1-7 \mathrm{~mm})$ varies from 35 to $61 \%$, and the aggregation factor $K_{\text {aggr }}$ is 3.98 . In the virgin soil, the primary mechanical particles are aggregated into micro- and macroaggregates up to $5 \mathrm{~mm}$ in diameter [21]. The formation of coarser aggregates $(>5 \mathrm{~mm})$ is ensured by the action of roots and by the soil cultivation. According to [15], the underground phytomass in the layer of $0-20 \mathrm{~cm}$ under fescue- feather grass steppe communities reaches $23.4 \mathrm{t} / \mathrm{ha}$, which is equivalent to $12 \mathrm{~g} / \mathrm{dm}^{3}$.

According to a scale of soil degradation [21], nondegraded dark chestnut soils should have an equilibrium bulk density of $<1.3 \mathrm{~g} / \mathrm{cm}^{3}$, the content of airdry aggregates of $0.25-10 \mathrm{~mm}$ in size of more than $70 \%$, and the portion of water-stable aggregates in the fraction of $>0.25 \mathrm{~mm}$ should be no less than $45 \%$. As seen from Table 1, virgin soils have the bulk density of less than $1.2 \mathrm{~g} / \mathrm{cm}^{3}$ and contain $>73 \%$ of dry aggregates $0.25-7 \mathrm{~mm}$. According to averaged data [28], the plow layer of dark-chestnut soils contains $11 \%$ air-dry aggregates $>0.25 \mathrm{~mm}$. According to [21], in the moderately and strongly degraded soils, the portion of aggregates of $0.25-10 \mathrm{~mm}$ should be $40-$ 60 and $<40 \%$, respectively. Among the studied dark chestnut soils, a high content of the silt-size aggregates $(<0.25 \mathrm{~mm})$ in the A horizon was only seen in the virgin soil (S9); in this soil, the contents of the silt-size $(<0.25 \mathrm{~mm})$ and fine granular aggregates $(0.5-1.0 \mathrm{~mm})$ were equal to $25-26 \%$.

As seen from Table 2, the soils of young fallow plots, the old-arable soil (S2), and the currently cultivated soil (S7), as well as other cultivated dark chestnut soils in the region according to averaged data [28], contain no more than $25 \%$ of water-stable aggregates $>0.25 \mathrm{~mm}$. This corresponds to the status of strongly degraded soils. The soils that were cultivated in the antique period and are under long-term fallow (S3, S4) at present belong to the category of slightly degraded soils. In some cases (S5), the structural properties of these soils are close to those in the virgin soils. It is important that the inner structure of the aggregates is somewhat different in the soils of the cultivated fields and long-term fallow. The study of thin sections [21] indicates that the water-stable aggregates in the soil of the fallow plot are penetrated by capillary pores with the walls strengthened by organic matter; they also contain abundant remains of 
LISETSKII, RODIONOVA

Table 2. Water stability of aggregates from the topsoil $(0-20 \mathrm{~cm})$ layer of dark chestnut soils in the area of ancient farming

\begin{tabular}{|c|c|c|c|c|c|c|c|c|c|}
\hline \multirow{2}{*}{ Land use } & \multirow{2}{*}{$\begin{array}{l}\text { Sampling } \\
\text { point }\end{array}$} & \multicolumn{4}{|c|}{ Amount of aggregates, \%; aggregate size, mm } & \multicolumn{4}{|c|}{ Agrophysical properties } \\
\hline & & $>3$ & $>1$ & $>0.25$ & $<0.25$ & $A$ & $A 1$ & $W, \%$ & $d, \mathrm{~mm}$ \\
\hline \multirow[t]{2}{*}{ Virgin land } & S8 & 6.8 & 23.5 & 43.81 & 56.2 & 52 & 73 & 63 & 0.94 \\
\hline & S9 & 1.1 & 25.0 & 46.55 & 53.5 & 63 & 55 & 74 & 0.75 \\
\hline \multirow[t]{3}{*}{ Postantique fallow } & S3 & 7.5 & 20.7 & 38.82 & 61.2 & 49 & 88 & 71 & 0.90 \\
\hline & S4 & 13.1 & 24.3 & 39.13 & 60.9 & 51 & 78 & 56 & 1.14 \\
\hline & S5 & 15.3 & 28.2 & 46.19 & 53.8 & 53 & 94 & 75 & 1.33 \\
\hline \multirow[t]{2}{*}{ Fallow 3-5 years } & $\mathrm{S} 2$ & 3.9 & 7.9 & 18.45 & 81.6 & 20 & 38 & 9 & 0.51 \\
\hline & S7 & 4.5 & 9.8 & 19.72 & 80.3 & 28 & 52 & 10 & 0.57 \\
\hline $\begin{array}{l}\text { Cropland in the area } \\
\text { of ancient farming }\end{array}$ & S1 & 6.4 & 14.6 & 28.62 & 71.4 & 31 & 59 & 12 & 0.76 \\
\hline
\end{tabular}

$A$ is the index of the water stability, $A 1$ is the Vadyunina-Korchagina criterion of the water stability $\left(A 1=C \mathrm{w}_{>0.25} / C_{>0.25} \times 100\right.$, where $C w_{>0.25}$ is the content of water-stable aggregates $>0.25 \mathrm{~mm}$, and $C_{>0.25}$ is the total content of aggregates $>0.25 \mathrm{~mm}$ ), $W$ is the water stability of the soil aggregates according to Andrianov, and $d$ is the mean weighted diameter of the water-stable aggregates.

Table 3. Chemical properties of the studied agrogenic soil sequence

\begin{tabular}{|c|c|c|c|c|c|c|c|c|c|}
\hline \multirow{2}{*}{$\begin{array}{l}\text { Soil } \\
\text { properties }\end{array}$} & \multicolumn{2}{|c|}{ Virgin land } & \multicolumn{4}{|c|}{ Postantique fallow } & \multicolumn{2}{|c|}{ Fallow $3-5$ years } & \multirow{2}{*}{$\begin{array}{l}\text { Cropland in the area } \\
\text { of ancient farming } \\
\mathrm{S} 1\end{array}$} \\
\hline & S8 & S9 & S3 & S4 & S5 & S6 & $\mathrm{S} 2$ & S7 & \\
\hline $\mathrm{pH}_{\mathrm{H}_{2} \mathrm{O}}$ & 7.86 & 7.70 & 7.08 & 7.05 & 7.10 & 7.25 & 6.80 & 8.10 & 7.15 \\
\hline $\mathrm{pH}_{\mathrm{KCl}}$ & 6.86 & 7.05 & 6.10 & 6.03 & 6.17 & 6.22 & 5.63 & 7.18 & 6.08 \\
\hline Humus, $\%$ & 3.00 & 3.57 & 2.61 & 2.25 & 2.35 & 1.86 & 1.29 & 2.04 & 1.63 \\
\hline $\mathrm{C}_{\mathrm{lab}}, \%$ & 0.043 & 0.066 & 0.096 & 0.081 & 0.082 & 0.042 & 0.045 & 0.058 & 0.069 \\
\hline $\mathrm{CO}_{2}, \%$ & 0.62 & 0.65 & 0.53 & 0.44 & 0.62 & 0.53 & 0.47 & 0.62 & 0.41 \\
\hline $\mathrm{N}_{\text {tot }}, \%$ & 0.144 & 0.165 & 0.140 & 0.126 & 0.119 & 0.098 & 0.081 & 0.098 & 0.084 \\
\hline $\mathrm{C}: \mathrm{N}$ & 12.06 & 12.53 & 10.79 & 10.34 & 11.43 & 10.99 & 9.22 & 12.05 & 11.24 \\
\hline $\mathrm{P}_{2} \mathrm{O}_{5}, \mathrm{mg} / \mathrm{kg}$ & 76 & 395 & 115 & 66 & 83 & 112 & 102 & 300 & 98 \\
\hline $\mathrm{K}_{2} \mathrm{O}_{2}, \mathrm{mg} / \mathrm{kg}$ & 260 & 235 & 130 & 150 & 137 & 75 & 112 & 1300 & 174 \\
\hline
\end{tabular}

the root system typical of the late stages of the succession on fallowed plots. The portion of coprolites in the old-arable soils is approximately the same as that in the virgin soils. The waterstability of the coprolites from the virgin soils is up to $89-95 \%$; in the soils of the long-term fallow plots, it is somewhat lower (86-94\%); and. in the soils of the cultivated fields, it is much lower (33-49\%).

The data on the water stability of the soil aggregates (Table 2) indicate that this characteristic is favored by the soil fallowing. This is seen both for the old-arable soils and the soils of long-term fallows. By analogy with the annual cyclic changes in some soil processes (drying-moistening, freezing-thawing), which result in the "selection" of thermodynamically stable results of the soil functioning, multiple transitions from the fallow state of the soils to their cultivation (and back) lead to some stabilization of the soil fertility level. Soil fallowing is an efficient measure to restore soil fertility in the dry steppe zone. This was realized in the ancient time and during the recent stage of the agricultural development of this area in the 18th-19th centuries. A soil cultivation system that included long-term soil fallowing was actively applied.

We analyzed data on the soils of this region obtained by Nabokikh in 1914 [20]. According to them, the humus content in the cultivated loamy and clayey southern chernozems reached $4.21 \pm 0.16 \%$ (3.24$5.60 \%)(n=48)$. At present, the humus content in the old-arable soils averages $2.24 \%$. The loss of organic matter from the soils of the modern plowland is estimated at about $50 \%$ in comparison with the virgin soils. In the soils subjected to long-term fallowing with some replenishment of the humus reserves, it is equal to $31 \%$ (Table 3). At the same time, the presence of a considerable pool of plant detritus in the virgin soils makes the humification processes in them somewhat different from those in the cultivated soils. Under the impact of the long-term soil cultivation, soil dehumification is 
TRANSFORMATION OF DRY-STEPPE SOILS

Table 4. Fractional composition of humus in the studied agrogenic soil sequence

\begin{tabular}{|c|c|c|c|c|c|c|c|c|c|c|c|}
\hline \multirow{2}{*}{ Land use } & \multirow{2}{*}{$\begin{array}{l}\text { Sampling } \\
\text { points }\end{array}$} & \multirow{2}{*}{$\mathrm{C}_{\text {org }}$} & \multicolumn{3}{|c|}{$\mathrm{C}_{\mathrm{ha}}$} & \multicolumn{4}{|c|}{$\mathrm{C}_{\mathrm{fa}}$} & \multirow{2}{*}{$\mathrm{C}_{\mathrm{ha}} / \mathrm{C}_{\mathrm{fa}}$} & \multirow{2}{*}{ NR } \\
\hline & & & 1 & 2 & 3 & 1a & 1 & 2 & 3 & & \\
\hline \multirow[t]{2}{*}{ Virgin land } & S8 & 1.74 & 0.90 & 13.77 & 9.47 & 2.13 & 0.24 & 1.96 & 4.20 & 2.83 & 67.33 \\
\hline & S9 & 2.07 & 0.45 & 15.68 & 9.86 & 2.02 & 0.05 & 1.69 & 4.82 & 3.03 & 65.43 \\
\hline \multirow[t]{4}{*}{ Postantique fallow } & S3 & 1.51 & 1.03 & 17.21 & 9.04 & 2.07 & 1.26 & 2.88 & 6.36 & 2.17 & 60.15 \\
\hline & S4 & 1.30 & 1.20 & 12.67 & 8.71 & 1.42 & 1.56 & 6.53 & 6.40 & 1.42 & 61.51 \\
\hline & S5 & 1.36 & 0.81 & 14.00 & 10.21 & 3.23 & 0.26 & 5.61 & 7.32 & 1.52 & 58.56 \\
\hline & S6 & 1.08 & 0.59 & 20.05 & 9.46 & 2.04 & 0.92 & 2.63 & 6.13 & 2.57 & 58.18 \\
\hline \multirow[t]{2}{*}{ Fallow $3-5$ years } & S2 & 0.75 & 0.47 & 14.10 & 12.40 & 3.10 & 0.93 & 7.29 & 6.82 & 1.49 & 54.89 \\
\hline & S7 & 1.18 & 0.93 & 15.93 & 9.41 & 1.18 & 0.93 & 3.48 & 4.90 & 2.50 & 63.24 \\
\hline $\begin{array}{l}\text { Cropland in the area } \\
\text { of ancient farming }\end{array}$ & S1 & 0.94 & 0.61 & 14.36 & 13.50 & 1.10 & 3.07 & 0.37 & 5.03 & 2.97 & 61.96 \\
\hline
\end{tabular}

$\mathrm{NR}$ is the content of nonhydrolyzable residue.

also accompanied by a considerable loss of nitrogen. Note that the loss of total $\mathrm{N}$ from the old-arable soils is even higher than the loss of humus (Table 4 ). The portion of labile $\mathrm{C}$ reaches $6.0-7.3 \%$ of $\mathrm{C}_{\text {org }}$ in the old-arable soils, lowers to $5.6 \%$ in the soils of the postantique fallow, to $4.9 \%$ in the currently plowed soils, and has its minimum $(2.5-3.2 \%)$ in the virgin soils.

With an increase in the intensity of the agrogenic impacts on soils, the portion of nonhydrolyzable residue in the composition of the humus becomes lower. This may attest to the less strong fixation of humic substances by the clay fraction in the long-cultivated soils. At the same time, as the nonhydrolyzable residue also includes plant detritus (with a high degree of decomposition), the rapid mineralization of the latter in the plowed soils may also contribute to a decrease in the content of nonhydrolyzable residue of the soil organic matter. The agrogenic transformation of dark chestnut soils is also accompanied by some increase in the relative content of fulvic acids as compared with humic acids. Though the first fractions of fulvic and humic acids (FA1 and HA1) are considered to be correlated, the content of FA1 shows a better correlation with the degree of agrogenic loads on the soils in comparison with the contents of HA1 and the sum of these fractions. If we suppose that fulvic acids represent the products of destruction of humic acids, the youngest fraction of fulvic acids (FA1) can be an informative indicator of the agrogenic loads on the dark chestnut soils.

The most considerable differences between the $\mathrm{pH}$ values of the water and salt suspensions $\left(\mathrm{pH}_{\mathrm{H}_{2} \mathrm{O}}\right.$ and $\left.\mathrm{pH}_{\mathrm{KCl}}\right)$ are observed in the cultivated soils. The total alkalinity is higher in the virgin soils. It lowers down in the arable soils and in the soils of long-term fallows, which makes it possible to assume that this is caused by a common reason, i.e., by the agrogenic changes in the soil regimes with a decrease in the concentration of the hydrolytically alkaline salts. This is in agreement with the tendency for a decrease in the content of carbonates in the soils subjected to agrogenic loads. Thus, the $\mathrm{CaCO}_{3}$ contents in the A horizon of the soils of the long-term fallow plots and currently plowed plots are 79 and $83 \%$ of the $\mathrm{CaCO}_{3}$ content in the A horizon of the virgin soils; respectively. This is explained by the fact that a periodically percolative type of soil water regime is established on plowed fields in contrast to the nonpercolative type typical of the virgin soils in the dry steppe zone [13].

It is known that solonetzic dark chestnut soils are characterized by a narrower ratio of exchangeable $\mathrm{Ca}^{2+}$ and $\mathrm{Mg}^{2+}(2-4: 1)$ in comparison with southern chernozems. Ourstudies in the area of ancient Olbia showed that this ratio in the A horizon is $4.55 \pm 0.95\left(x \pm t_{05} S_{x}\right.$; $n=12$ ).

Geochemical features of the series of agrogenic soils. The bulk elemental composition of the soils found near settlements and in the zones of various economic activities allows us to judge the character of the anthropochemical processes [1]. In the studied soils, independently from their agrarian history, the accumulation of As and $\mathrm{Mn}$ in the topsoil horizons takes place (Table 5). In the dark chestnut soils, the mobility of As is decreased, and its relative accumulation in the topsoil is explained by the evaporative concentration. A high level of As accumulation in the topsoil in comparison with its relatively low content in the parent material is observed. Its average content in the topsoil reaches $7.5 \mathrm{mg} / \mathrm{kg}$. In the soil of plot S7, the concentration of As approaches the lower limit of the maximum permissible concentration $(10 \mathrm{mg} / \mathrm{kg})$. As shown in [41], the behavior of As in the soils has much in common with the behavior of phosphates. In the soils subjected to the agrogenic transformation, the concentration of As is correlated with the concentration of $\mathrm{P}_{2} \mathrm{O}_{5}$. The concentration of phosphates in the topsoil is related to the biological accumulation and to 
Table 5. Bulk elemental composition of soils in the studied agrogenic soil sequence

\begin{tabular}{|c|c|c|c|c|c|c|c|c|c|c|c|c|}
\hline \multirow{3}{*}{$\begin{array}{c}\text { Chemical } \\
\text { elements } \\
\text { and geochemical } \\
\text { indices }\end{array}$} & \multirow{3}{*}{$\begin{array}{l}\text { Measure- } \\
\text { ment unit }\end{array}$} & \multicolumn{4}{|c|}{ Virgin land } & \multirow{2}{*}{\multicolumn{4}{|c|}{ Postantique fallow }} & \multirow{2}{*}{\multicolumn{2}{|c|}{ Fallow of $3-5$ years }} & \multirow{3}{*}{$\begin{array}{l}\text { Cropland } \\
\text { in the area } \\
\text { of ancient } \\
\text { farming }\end{array}$} \\
\hline & & \multicolumn{2}{|c|}{ Kozyrka } & \multicolumn{2}{|c|}{ Krestovyi Ravine } & & & & & & & \\
\hline & & S8 & $\operatorname{Pr} 8$ & S9 & $\operatorname{Pr} 9$ & $\mathrm{~S} 3$ & S4 & $\mathrm{S} 5$ & S6 & $\mathrm{S} 2$ & S7 & \\
\hline $\mathrm{SiO}_{2}$ & $\%$ & 67.29 & 61.87 & 72.17 & 50.54 & 71.77 & 74.08 & 69.55 & 71.49 & 72.30 & 73.81 & 73.65 \\
\hline $\mathrm{Al}_{2} \mathrm{O}_{3}$ & $"$ & 10.39 & 10.44 & 8.67 & 7.41 & 8.62 & 9.43 & 8.05 & 8.20 & 9.49 & 8.96 & 9.96 \\
\hline $\mathrm{Fe}_{2} \mathrm{O}_{3}$ & $"$ & 4.13 & 3.48 & 2.91 & 1.90 & 2.98 & 2.98 & 2.81 & 2.81 & 3.05 & 2.75 & 3.01 \\
\hline $\mathrm{CaO}$ & $"$ & 1.24 & 6.93 & 1.17 & 16.78 & 0.92 & 0.87 & 0.90 & 0.89 & 0.80 & 0.93 & 0.81 \\
\hline $\mathrm{MgO}$ & $"$ & 1.07 & 2.18 & 0.82 & 3.59 & 0.81 & 0.54 & 0.82 & 0.73 & 0.73 & 0.75 & 0.78 \\
\hline $\mathrm{Na}_{2} \mathrm{O}$ & $"$ & 1.47 & 2.17 & 1.41 & 1.74 & 1.46 & 1.11 & 1.26 & 1.02 & 1.46 & 1.57 & 1.31 \\
\hline $\mathrm{K}_{2} \mathrm{O}$ & $"$ & 2.25 & 1.80 & 2.28 & 1.46 & 2.05 & 2.16 & 1.93 & 1.95 & 2.07 & 2.38 & 2.13 \\
\hline $\mathrm{TiO}_{2}$ & $"$ & 0.73 & 0.69 & 0.64 & 0.52 & 0.68 & 0.68 & 0.64 & 0.69 & 0.65 & 0.63 & 0.67 \\
\hline $\mathrm{P}_{2} \mathrm{O}_{5}$ & $"$ & 0.13 & 0.13 & 0.17 & 0.15 & 0.13 & 0.12 & 0.12 & 0.11 & 0.11 & 0.15 & 0.11 \\
\hline $\mathrm{MnO}$ & $\mathrm{mg} / \mathrm{kg}$ & 813 & 657 & 672 & 303 & 674 & 694 & 562 & 653 & 646 & 618 & 613 \\
\hline $\mathrm{V}$ & $"$ & 85.93 & 75.46 & 63.98 & 55.71 & 68.55 & 75.18 & 66.93 & 68.14 & 65.79 & 55.33 & 72.61 \\
\hline $\mathrm{Cr}$ & $"$ & 80.50 & 75.53 & 68.52 & 54.86 & 71.07 & 74.55 & 64.08 & 67.84 & 68.35 & 55.25 & 70.70 \\
\hline $\mathrm{Zn}$ & $"$ & 66.43 & 57.50 & 45.18 & 29.73 & 46.51 & 38.30 & 40.90 & 41.05 & 43.88 & 47.30 & 44.71 \\
\hline $\mathrm{Ni}$ & $"$ & 42.30 & 37.71 & 24.59 & 27.93 & 25.15 & 29.06 & 26.88 & 24.70 & 28.49 & 23.99 & 28.63 \\
\hline $\mathrm{Cu}$ & $"$ & 39.43 & 28.41 & 20.84 & 33.11 & 16.39 & 31.26 & 18.21 & 16.96 & 18.68 & 12.93 & 20.95 \\
\hline $\mathrm{Pb}$ & $"$ & 16.34 & 18.85 & 17.55 & 15.16 & 14.27 & 28.92 & 9.12 & 15.60 & 19.31 & 8.64 & 15.55 \\
\hline As & $"$ & 9.57 & 7.10 & 5.18 & 1.89 & 6.99 & 4.97 & 7.93 & 6.14 & 8.05 & 10.30 & 8.58 \\
\hline $\mathrm{SiO}_{2}: \mathrm{R}_{2} \mathrm{O}_{3}$ & $\begin{array}{c}\text { Dimension- } \\
\text { less }\end{array}$ & 3.72 & 3.61 & 5.05 & 4.47 & 5.00 & 4.86 & 5.18 & 5.26 & 4.69 & 5.14 & 4.64 \\
\hline$K \mathrm{e}$ & $"$ & 11.15 & 4.73 & 12.71 & 2.14 & 13.70 & 15.83 & 14.18 & 15.54 & 14.28 & 13.10 & 14.62 \\
\hline$R$ & $»$ & 1.16 & 1.00 & 1.19 & 1.00 & 1.18 & 1.32 & 1.13 & 1.15 & 1.19 & 1.04 & 1.23 \\
\hline
\end{tabular}

$\mathrm{S}(\mathrm{No}) \longrightarrow$ soil sampling point and its number, $\mathrm{Pr}(\mathrm{No})$ —sampling point of parent material and its number, Ke-coefficent of eluviation, and $R$-coefficient of accumulation of trace elements. 
the added fertilizers, including superphosphate. The maximum contents of the total and available phosphorus were found in the soil of the arable field (S7) and in the adjacent virgin soil (S9). It is probable that the accumulation of phosphorus in the latter soil was due to the additional input of phosphorus compounds from the adjacent cultivated field with the surface runoff. The phosphorus content in the other virgin soil (S8) is considerably lower. The content of $\mathrm{MnO}$ in the upper horizon $(0-20 \mathrm{~cm})$ of the dry steppe soils is $27 \%$ higher than that in the soils of the Black Sea in general (550 $\mathrm{mg} / \mathrm{kg}$, [23]). In the agrogenic soils studied by us, the $\mathrm{MnO}$ content varies from 600 to $800 \mathrm{mg} / \mathrm{kg}$. The anthropogenic influence on the soils is also diagnosed by some decrease (by 8.5\%) in the total content of elements actively consumed by plants ( $\mathrm{P}, \mathrm{Ca}, \mathrm{K}, \mathrm{Mg}, \mathrm{Mn}$, and $\mathrm{Cu}$ ) in the soils with a long history of their agricultural development in comparison with the virgin soils. The values of the $R$ coefficient calculated for 13 elements shows that the topsoil $(0-20 \mathrm{~cm})$ horizon of the old-arable soil is not depleted of these elements in general, though the ratios between them in the virgin soil and in the old-arable soils are different. The virgin (reference) soil is richer in the bulk P (by 1.55 times), $\mathrm{Ca}$ (by 1.44 times), and Co (by 1.24 times) and is impoverished in As, $\mathrm{V}$, and $\mathrm{Ni}$. The latter three elements are considered to be elements of moderate toxicity $(\mathrm{V}>\mathrm{Ni}>\mathrm{As})$ [6], and their concentrations in the old-arable soil are 1.14-1.16 (for $\mathrm{V}$ and $\mathrm{Ni}$ ) and 1.66 times (As) higher than those in the virgin soil.

Agrogenic transformation of dry steppe soils. To judge the agrogenic transformation of soils under the impact of long-term farming practices, it is important to take into account some objective indicators of the irreversible soil changes. As indicated in [36], the most exhausting explanation for the evolutionary changes should be based on the analysis of the processes driving these changes. Thus, we can analyze the temporal stages of the development of some object and interpret them in terms of the characteristic processes. This method can be referred to as the method of processoriented reconstruction [22].

We used the data on 30 different soil characteristics (Tables 1-5) and arranged them in decreasing order. ${ }^{1}$ The studied soils were arranged in a sequence reflecting the duration and intensity of the agrogenic impact on them. Thus, we could compare the ranked variables (soil properties and agrogenic impact on the soils) [39]. Spearman's rank correlation coefficient $r_{S}$ equal to 0.6 was taken as a criterion to judge the correlation between the two sets. This coefficient marks a transition from the moderately to strongly correlated variables. This method allowed us to identify 13 soil properties as the moist informative indicators of agrogenesis. Among these properties, only the coefficient of eluviation $K_{\mathrm{e}}$ and the content of the first fraction of fulvic acids (FA1) displayed a monotonously decreas-

\footnotetext{
${ }^{1}$ In some cases, the soil characteristics had similar values.
}

ing dependence $\left(r_{S}<0\right)$ on the duration of the agrogenic impacts on the soils. The degree of agrogenic influence on the soils is seen in the activation of the processes of eluviation, decalcification, and dehumification with an increase in the relative content of fulvic acids (especially, their first fraction FA1). For the remaining eleven soil characteristics (the sum of the agronomically valuable aggregate fractions of $0.25-$ $7.0 \mathrm{~mm}$; the aggregation coefficient $K_{\text {aggr }}$; the portion of coprolites in the agronomically valuable aggregates; the water stability of the soil aggregates $A$ and $W$; the $\mathrm{pH}$ of the salt suspension $\left(\mathrm{pH}_{\mathrm{KCl}}\right)$; the $\mathrm{C}: \mathrm{N}$ ratio; and the contents of $\mathrm{CO}_{2}$, humus, nonhydrolyzable residue, and $\mathrm{N}$ ), a general tendency for their decrease with an increase in the duration and intensity of the agrogenic impacts on the soils is observed. Then, we analyzed the mutually correlated indicators of the agrogenesis as judged from the number of their values fitting the requirement $r_{S}>0.6$. For the water stability of the agronomically valuable aggregates, values of $r_{S}>0.6$ were observed in 9 cases; for the $\mathrm{C}: \mathrm{N}$ ratio, humus content, $\mathrm{N}$ content, and the content of FA1, in 8 cases; for the $\mathrm{CO}_{2}$ content and coefficient of eluviation $K_{e}$, in 7 cases; for the $\mathrm{pH}_{\mathrm{KCl}}$, in 5 cases; for the water stability of the soil aggregates $W$, the content of nonhydrolyzable residue, and the portion of coprolites in the agronomically valuable aggregates, in 4 cases; and for the total content of agronomically valuable aggregates $(0.25-7 \mathrm{~mm})$ and the aggregation coefficient $K_{\text {aggr }}$, in 3 cases.

The available data on the impact of modern farming on the physicochemical degradation of chernozemic soils (as compared with the virgin soils) were generally confirmed for the dark chestnut soils of the dry steppe zone. The soils of modern plowed fields differ from the virgin soil in the lower contents of humus and nitrogen; the lower portion of coprolites in the agronomically valuable aggregates; the lower values of $K_{\text {aggr }}, A$, and $W$; and the higher content of FA1. These differences are statistically significant at the $5 \%$ significance level.

In order to reveal reliable differences between the studied soils according to the specified indicators of the agrogenic transformation, we used the results of the variance analysis. In particular, the least significant difference $\mathrm{LSD}_{05}$ was calculated. This criterion was used to judge the sensitivity of different indicators to the duration of agrogenic impacts on the soils.

In general, the integral effect of the agrogenic transformation of the topsoil horizon during the past 150 years of continuous cultivation loads is seen in the decreased the water stability of the soil aggregates. This is caused by a number of factors, including the loss of organic matter, the change in the quality of the humus (with some rise in the content of $\mathrm{N}$ and a considerable rise in the relative content of the first fraction of fulvic acids), and the lower impact of plant roots 
and soil fauna on the formation of the soil structure in the cultivated soils.

During the very long period of "fallowing" of the soils cultivated in the antique period (from the 4th to the 20th centuries AD), the physicochemical properties of the former plow layer (postagrogenic horizon) were virtually restored to the level typical of the zonal virgin soils, except for the humus content and the content of FA1. The portion of coprolites in the agronomically valuable aggregates of these soils is also somewhat lower (by $7-9 \%$ ) than that in the virgin soils. The generalized data indicate that the total content of organic matter in the soils of long-term fallow plots $(2.82 \pm 0.57 \%)$ is also lower than that in the virgin soils $(3.28 \pm 0.66 \%)$ (the difference reaches $14 \%$ ). During sixteen centuries of the soil fallowing, the accumulation of humus in the postagrogenic soils has been controlled by several factors, including the phytocenotic factor (the phytomass structure in the virgin steppe cenoses differs from that in the cenoses of the postagrogenic succession), the soil factor (i.e., the specificity of the organic matter transformation in the postagrogenic soils), and the evolutionary climatic factor (the specificity of the climatic conditions in that period). According to paleogeographic data, there were at least four xeromorphic phases lasting for $100-$ 300 years during that period, including the so-called "medieval minimum of pedogenesis" with its extreme point about 950 years ago [9].

As indicated above, the humus content in the soils of the long-term postantique fallows has reached $86 \%$ of the humus content in the virgin soils. It can be supposed that the dynamics of the humus accumulation in the initially humified substrate of the plowed soils of the antique period during this chronointerval differ from the dynamics of the humus accumulation (soil ontogenesis) in the full-Holocene virgin soils. This hypothesis requires additional testing.

The specificity of the old-arable soils (the soils cultivated in the antique period and in the past 150 years) in comparison with the soils cultivated in the past 150 years is clearly manifested in the values of only two soil characteristics: the coefficient of aggregation $K_{\text {agor }}$ and the content of the first fraction of fulvic acids FA1. The coefficient of aggregation in the old-arable soils is higher owing to a lower content of the aggregate fraction $<0.25 \mathrm{~mm}$, and the content of FA1 in them exceeds that in the recently cultivated soils by more than three times. Thus, the content of the first fraction of fulvic acids can be considered the most reliable and universal indicator of the changes in the soils of the dry steppe zone under the impact of agrogenic loads differing in their duration.

The following scenario of the agrogenic transformation of dark chestnut soils in the rural area of the antique polis during the past millennia can be suggested. Initially (beginning from the 6th century BC), ancient farmers practiced shifting cultivation and let the arable soils rest for no less than $8-10$ years to restore their fertility (the organic matter content, the soil structure, and the soil water and air regimes). After the land plots were fixed in space and the land use pattern was stabilized, the degree of agrogenic loads on the soils increased to produce commodity crops. Active agrogenic turbation disturbs the equilibrium state of the soil system; its further regime has an oscillatory character. Under these conditions, even small periodic impacts on the soil system can lead to greater amplitudes of oscillations. This phenomenon is similar to resonance [25]. It may result in the destruction of a misbalanced system.

The duration of this period of ancient farming within the established system of land plots is comparable with the duration of the recent stage of agrarian history. Together with the initial stage of shifting cultivation, the duration of ancient farming exceeds the duration of the recent stage by two times. The processes of soil degradation under the impact of farming loads in the ancient period were similar to those observed at present: the loss of nutrients with harvested crops, enhanced mineralization of the humus upon soil tillage, disaggregation of the soil mass, lower activity of soil mesofauna, wind erosion, etc.

During the postagrogenic functioning of the biogeocenoses, positive feedback relationships ensured the adaptation of the system to the new conditions. With time, the rate of changes in the soil properties decreases until the new equilibrium state is reached. The time required to reach the new equilibrium may differ for different processes [8].

The soils cultivated in the antique period and in the past 150 years do not differ much from the soils cultivated only in the past 150 years. However, the former soils are characterized by somewhat higher values of the aggregation coefficient (in the topsoil horizon) and in the contents of the first fraction of fulvic acids and the third fraction of humic acids (humic acids bound with the clay fraction and stable sesquioxides). As shown earlier [13], the soils cultivated in the antique period are characterized by higher rates of humus formation and deeper boundaries of effervescence and salt accumulations.

In the study of geosystems, it is important to know not only their genesis and age but also their functional relationships. The time of functioning under different conditions should be known [4]. For the studied soils with several stages of their agrogenic evolution, the history of the soil functioning was very complicated. The time required for the soil processes initiated by changes in the soil state to reach the new quasi-equilibrium state is known as the characteristic response time. It is different for different processes. For the entire bio-abiotic soil system, the processes with great characteristic response times can be considered the "products" of the processes with shorter characteristic response times [3]. In the system of indicators of the agrogenic transformation of the physicochemical properties of the dry steppe soils, several hierarchical 


\section{TRANSFORMATION OF DRY-STEPPE SOILS}

levels can be distinguished. In the upper part of the humus-accumulative horizons, agrogenic loads on the soil lead to changes in the soil properties controlled by the processes with short ( $<10$ years) and medium ( $10-$ 50 years) characteristic times [11]. In our study, these processes are diagnosed by changes in the following indicators: the sum of agronomically valuable aggregates $(0.25-7.0 \mathrm{~mm})$; the coefficient of aggregation $K_{\text {aggr }}$; the portion of coprolites in the agronomically valuable aggregates; the water stability of the soil aggregates $(A$ and $W)$; the $\mathrm{pH}_{\mathrm{KCl}}$; the $\mathrm{C}: \mathrm{N}$ ratio; the coefficient of eluviation $K_{e}$; and the contents of the $\mathrm{CO}_{2}$ of carbonates, humus, fulvic acids of the first fraction (FA1), nonhydrolyzable residue, and nitrogen. Slow processes [11] are manifested in the entire profile of old-arable soils; they can be diagnosed by transformation of the profiles of soil humus and carbonates, the development of eluviation, the loss of solonetzic features in the physical stage of the soils, the enhancement of soil weathering, and the formation of compound macroaggregates against the background of the high microaggregation of the soil mass [13]. These processes ensure the irreversibility of the soil evolution with preservation of the stable stratified solid-phase carcass of the soil body [11].

\section{CONCLUSIONS}

(1) The degree of agrogenic loads on the dark chestnut soils in the rural area of the ancient polis (6th century BC-4th century AD) is diagnosed by thirteen indicative soil properties (for the layer of $0-$ $20 \mathrm{~cm}$ ), including the physical properties (the coefficient of aggregation, the content of agronomically valuable $(0.25-7 \mathrm{~mm})$ aggregate fractions and the portion of coprolites in them, and the water stability of the aggregate fractions of $0.25-7.0 \mathrm{~mm}$ and $0.5-5.0 \mathrm{~mm}$ ) and the chemical properties (the coefficient of eluviation; the contents of organic matter, nitrogen, and carbonates; the portions of nonhydrolyzable residue and the first fraction of fulvic acids in the composition of humus; the $\mathrm{C}: \mathrm{N}$ ratio; and the soil $\mathrm{pH}$ ). In the studied series of agrogenic changes from the virgin soils to the soils cultivated in the antique period and in the recent past and the soils with different durations of the fallow stage, some of these indicative soil properties proved to be mutually correlated. The best correlation was observed between the water stability of the agronomically valuable aggregate fractions; the $\mathrm{C}: \mathrm{N}$ ratio; the coefficient of eluviation; and the contents of carbonates, organic matter, nitrogen, and fulvic acids of the first fraction.

(2) The applied method of the factor series of agrogenic changes in the soils showed that the changes in the mean weighted diameter of the water-stable aggregates, the Vadyunina-Korchagina criterion of the water stability of the soil aggregates, the coefficient of accumulation of trace elements $(\mathrm{Mn}, \mathrm{Zn}, \mathrm{Cu}, \mathrm{Ti}, \mathrm{Ni}$, $\mathrm{Cr}$, and $\mathrm{V}$ ), the $\mathrm{SiO}_{2}: \mathrm{R}_{2} \mathrm{O}_{3}$ ratio, the $\mathrm{pH}$ of the soil water suspension, the contents of available $\mathrm{P}$ and $\mathrm{K}$, the $\mathrm{C}_{\mathrm{ha}} / \mathrm{C}_{\mathrm{fa}}$ ratio, the portion of labile humus, and the contents of different fractions of humus (except for the first fraction of fulvic acids in response to different durations and intensities of agrogenic loads) are statistically unreliable. This attests either to the low sensitivity of these soil properties to the agrogenic loads or to the possibility of reversible changes in them with a characteristic time shorter than that of the stable indicators of the agrogenically induced soil transformation.

(3) The agrotechnologies applied by ancient farmers were aimed at the restoration of the soil fertility; in essence, they were based on the principles of management of self-organizing systems [8]. The purposeful periodic initiation of the natural processes of reproduction of the soil fertility (during the stage of land fallowing) can be considered a measure realizing small resonance impacts on the soil system with their proper distribution in time to ensure self-organization processes. In the case of the large-scale development of soil degradation phenomena in the modern agrolandscapes, it may be reasonable to the adapt ancient farming technologies to the modern epoch. As argued in [31], the synthesis of the advantages of traditional farming technologies with modern technologies of intensive agriculture seems to be promising.

\section{ACKNOWLEDGMENTS}

This study was performed within the framework of the implementation of the base part of the state assignment of the Ministry of Education and Science of the Russian Federation for the Belgorod State National Research University on the organization of scientific research (2014/420-1).

\section{REFERENCES}

1. E. I. Aleksandrovskaya and A. L. Aleksandrovskii, "Anthropochemistry and soil science," Eurasian Soil Sci. 38 (7), 703-712 (2005).

2. P. I. Andrianov, "On the strength of soil clod and methods of its determination," Pochvovedenie, No. 2, 96101 (1947).

3. A. D. Armand and V. O. Targulian, "Principle of complementarity and specific time in geography," in Systems Studies (Nauka, Moscow, 1974), pp. 146-153.

4. N. V. Bagrov, V. A. Bokov, and I. G. Chervanev, "Spatiotemporal relationships in self-organization of geosystems," Geopolit. Ekogeodin. Reg., No. 1, 12-20 (2005).

5. Yu. G. Vinogradov, "Polis in the Northern Black Sea region," in Ancient Greece (Nauka, Moscow, 1983), Vol. 1, p. 380.

6. Yu. N. Vodyanitskii, "Standards for the contents of heavy metals and metalloids in soils," Eurasian Soil Sci. 45 (3), 321-328 (2012).

7. G. P. Garbuzov, "Archaeological studies and remote survey of the Earth from space," Ross. Arkheol., No. 2, 45-55 (2003). 


\section{LISETSKII, RODIONOVA}

8. P. V. Goleusov, Doctoral Dissertation in Geography (Belgorod, 2012).

9. I. V. Ivanov and F. N. Lisetskii, "Correlation of soil formation rthms with periodicity of solar activity over the last 5000 years," Dokl. Akad. Nauk SSSR Ross. Akad. Nauk, Earth Sci. Section, 340 (1), 189-194 (1996).

10. N. A. Karavaeva, S. N. Zharikov, and A. E. Zharikov, "Plowed soils in the nonchernozemic region: a processevolutionary approach to the study," Pochvovedenie, No. 11, 114-125 (1985).

11. F. I. Kozlovskii, Modern Natural and Anthropogenic Processes of Soil Evolution (Nauka, Moscow, 1991) [in Russian].

12. S. D. Kryzhitskii, S. B. Buiskikh, A. V. Burakov, et al., Rural Region of Olbia (Naukova Dumka, Kyiv, 1989) [in Russian].

13. F. N. Lisetskii, "Agrogenic transformation of soils in the dry steppe zone under the impact of antique and recent land management practices," Eurasian Soil Sci. 41 (8), 805-817 (2008). doi: 10.1134/S1064229308080024

14. F. N. Lisetskii, "Soil catenas in archeological landscapes," Eurasian Soil Sci. 32 (10), 1084-1093 (1999).

15. F. N. Lisetskii, The Spatial and Temporal Organization of Agrolandscapes (Belgorod State University, Belgorod, 2000) [in Russian].

16. F. N. Lisetskii, P. V. Goleusov, and O. A. Chepelev, "The development of chernozems on the Dniester-Prut interfluve in the Holocene," Eurasian Soil Sci. 46 (5), 491504 (2013). doi: 10.7868/S0032180X13050109

17. F. N. Lisetskii and E. I. Ergina, "Soil development on the Crimean Peninsula in the Late Holocene," Eurasian Soil Sci. 43 (6), 601-613 (2010). doi: 10.1134/S1064229310060013

18. F. N. Lisetskii, A. A. Svetlichnyi, and S. G. Chernyi, Recent Developments in Erosion Science, Ed. by A. A. Svetlichnyi (Konstanta, Belgorod, 2012) [in Russian].

19. Materials on Land Evaluation in Kherson Province, Vol. 1: Odessa District (Kherson, 1883) [in Russian].

20. Materials on Soil Studies in Kherson Province (Odessa, 1915), No. 11.

21. V. V. Medvedev, Soil Structure: Genesis, Classification, Evolution, Geography, Monitoring, and Protection (13 Tipografiya, Kharkov, 2008) [in Russian].

22. S. V. Meien, "Principles of historical reconstruction in biology," in Systems and Evolution (Nauka, Moscow, 1984), pp. 7-32.

23. Microelements in Soils of the Soviet Union (Moscow State University, Moscow, 1973), No. 1.

24. V. A. Nikolaev, Problems of Regional Landscape Science (Moscow State University, Moscow, 1979) [in Russian].

25. Yu. F. Novikov and A. K. Istrati, Evolution of Agricultural Methods and the Problem of Erosion (Shtiintsa, Chisinau, 1983) [in Russian].

26. I. Pachoskii, Wild Cereals of Kherson Province (Kherson, 1913) [in Russian].

27. V. E. Postnikov, South Russian Peasant Economy (Moscow, 1891) [in Russian]

28. Soils of Crimean Region (Simferopol, 1969) [in Russian].
29. T. N. Smekalova, "Comparison of orthogonal systems of land demarcation in European Bosporus and Kherson (Tarkhankut Peninsula)," Drevnosti Bospora, No. 10, 389-415 (2006).

30. A. V. Sovetov, On Farming Systems (Librikom, Moscow, 2010) [in Russian].

31. V. M. Fedorov, Biosphere-Farming-Humankind (Agropromizdat, Moscow, 1990) [in Russian].

32. Y. G. Chendev, I. V. Ivanov, and L. S. Pesochina, "Trends of the natural evolution of chernozems on the East European Plain," Eurasian Soil Sci. 43 (7), 728 736 (2010).

33. K. V. Shishkin, "Aerial survey method as the source for historical topography of Olbia and its suburbs," Sov. Arkheol., No. 3, 235-242 (1982).

34. C. E. Cordova and P. H. Lehman, "Holocene environmental change in southwestern Crimea (Ukraine) in pollen and soil records," The Holocene 15, 263-277 (2005).

35. M. Groodman-Elgar, "Evaluating soil resilience in long-term cultivation: a study of pre-Columbian terraces from Paca Valley, Peru," J. Archaeol. Sci. 35, 3072-3086 (2008).

36. D. Harvey, Explanation in Geography (Edward Arnold, London, 1969).

37. J. A. Homburg and J. A. Sandor, "Anthropogenic effects on soil quality of ancient agricultural systems of the American Southwest," Catena 85 (2), 144-154 (2011).

38. A. V. Karjaka, "The demarcation system of the agricultural environment of Olbia Pontike," in Meetings of Cultures in the Black Sea Region: Between Conflict and Coexistence, Ed. by P. G. Bilde and J. H. Petersen (University Press, Aarhus, 2008), pp. 181-192.

39. F. N. Lisetskii and M. E. Rodionova, "Soil and landscape changes in ancient agricultural areas (exemplified by antique Olbia)," Geogr. Nat. Resour. 33 (4), 327335 (2012). doi: 10.1134/S1875372812040117

40. G. Liu, L. Li, L. Wu, et al., "Determination of soil loss tolerance of an Entisol in Southwest China," Soil Sci. Soc. Am. J. 73 (2), 412-417 (2009).

41. P. O'Neill, "Arsenic," in Heavy Metals in Soil (Blackie and Son, London, 1990), pp. 83-99.

42. J. A. Sandor, "Ancient agricultural terraces and soils," in Footprints in the Soil: People and Ideas in Soil History (Elsevier, Amsterdam, 2006), pp. 505-534.

43. J. A. Sandor, P. L. Gersper, and J. W. Hawley, "Prehistoric agricultural terraces and soils in the Mimbres Area, New Mexico," World Archaeol. 22, 70-86 (1990).

44. D. M. Shaw, Interprétation Geochimique des éléments en Traces dans les Roches Cristallines (Masson, Paris, 1964).

45. Surveying the Greek Flora. Black Sea Region in a Comparative Perspective Black Sea Studies, Ed. by P. G. Bilde and V. F. Stolba (University Press, Aarhus, 2006).

46. H. Walkington, "Soil science applications in archaeological contexts: a review of key challenges," Earth-Sci. Rev. 103, 122-134 (2010).

Translated by D. Konyushkov 